\title{
BMJ Open Biology of selective caries removal: a systematic scoping review protocol
}

\author{
Matthias Widbiller (D , , ${ }^{1}$ Rita Weiler, ${ }^{1}$ Helge Knüttel, ${ }^{2}$ Kerstin M Galler, \\ Wolfgang Buchalla, ${ }^{1}$ Konstantin J Scholz (iD ${ }^{1}$
}

To cite: Widbiller M, Weiler R, Knüttel $\mathrm{H}$, et al. Biology of selective caries removal: a systematic scoping review protocol. BMJ Open 2022;12:e061119. doi:10.1136/ bmjopen-2022-061119

- Prepublication history and additional supplemental material for this paper are available online. To view these files, please visit the journal online (http://dx.doi.org/10.1136/ bmjopen-2022-061119)

Received 14 January 2022 Accepted 26 January 2022

Check for updates

(C) Author(s) (or their employer(s)) 2022. Re-use permitted under CC BY-NC. No commercial re-use. See rights and permissions. Published by BMJ.

${ }^{1}$ Department of Conservative Dentistry and Periodontology, University Hospital Regensburg, Regensburg, Germany ${ }^{2}$ University Library, University of Regensburg, Regensburg, Germany

Correspondence to

Dr Matthias Widbiller;

matthias.widbiller@ukr.de

\section{ABSTRACT}

Introduction Primary goal of restorative caries therapy is to preserve pulp vitality and the dentition. Whereas the conventional approach of complete caries removal aims at the elimination of all affected substances without regard to losses of hard tissue or pulp vitality, the innovative concept of selective caries removal (SCR) is characterised by a targeted and non-invasive excavation. It presents a lower risk of accidental pulp exposure, which reportedly has a positive effect on tooth survival. Although clinical data show the benefits of SCR, knowledge about the biological processes during this procedure in the pulp-dentine complex of permanent teeth is scarce. Hence, the aim of this work is to systematically scope the existing literature and map the existing evidence according to the Preferred Reporting Items for Systematic reviews and Meta-Analyses extension for Scoping Reviews guideline. This protocol details the scoping review's methodological and analytical approaches.

Methods and analysis First, a structure was established (phase I) as basis for a systematic scoping of literature (phase II). In the course of phase I, a total of 100 systematic reviews related to selective caries removal were searched in MEDLINE and information or theories on the biological processes were extracted. During the entire procedure, two reviewers independently screened the articles, and controversies were mediated by vote of a third reviewer. Eventually, it became apparent that different biological explanations can be organised into four categories: pulp response, cavity seal, remaining bacteria and cavity liner. Based on this structure, a search for original publications (phase II) will be performed and retrieved evidence will be assembled using a predefined conceptual framework.

Ethics and dissemination As primary data will not be included in this study, ethical approval is not required. Findings will be disseminated through peer-reviewed publications, conference presentations and summaries for key stakeholders.

\section{INTRODUCTION}

Dental caries is a disease showing an estimated worldwide prevalence of more than 2 billion patients in 2013, where dental hard tissues, that is, the superficial enamel and underlying dentine, are destroyed by the metabolites of bacteria with high acidurance and acidogenic activity. ${ }^{12}$ Cavities in deciduous or permanent teeth are the consequence of this decay and

\section{Strengths and limitations of this study}

This scoping review protocol is the first systematic approach to map evidence about the biology behind selective caries removal in the permanent dentition.

- A detailed scoping structure was established from systematic screening of the literature.

- The narrative summary follows a clear concept and structure, where the type of the original work in regard to the evidence level is considered.

Due to the broad nature of the subject matter, it is possible that relevant literature may not be identified by our comprehensive search strategy.

gradually advance towards the dental pulp, a multifunctional tissue within the core of the tooth. During carious degradation, the originally hard dental tissues are transformed into a softened mass, which is largely composed of dead microorganisms, metabolic products and organic material. ${ }^{3}$ Characterising these lesions, it is important to consider the depth of the lesion as well as the affected tissues. Whereas shallow cavities involve only enamel, deeper lesions extend into dentine and may penetrate the pulp chamber if no intervention occurs (figure 1). When treating carious lesions, the primary goal is to preserve pulp vitality, ${ }^{2}$ which has been described to be a key factor in securing the tooth's long-term survival. ${ }^{45}$

Although different definitions of a 'deep carious lesion' can be found in the literature, ${ }^{6}$ the statement of the European Society of Endodontology (ESE) officially defines a 'deep carious lesion' as reaching the inner quarter of dentine while leaving a zone of hard or firm dentine between the lesion and the pulp, which can be confirmed radiographically. ${ }^{7}$ Depending on the depth of the lesion and the thickness of the residual dentine layer protecting the pulp, therapeutic concepts range from non-invasive hygienic and preventive interventions to complete removal of carious tissue and subsequent restoration. While non-invasive procedures 

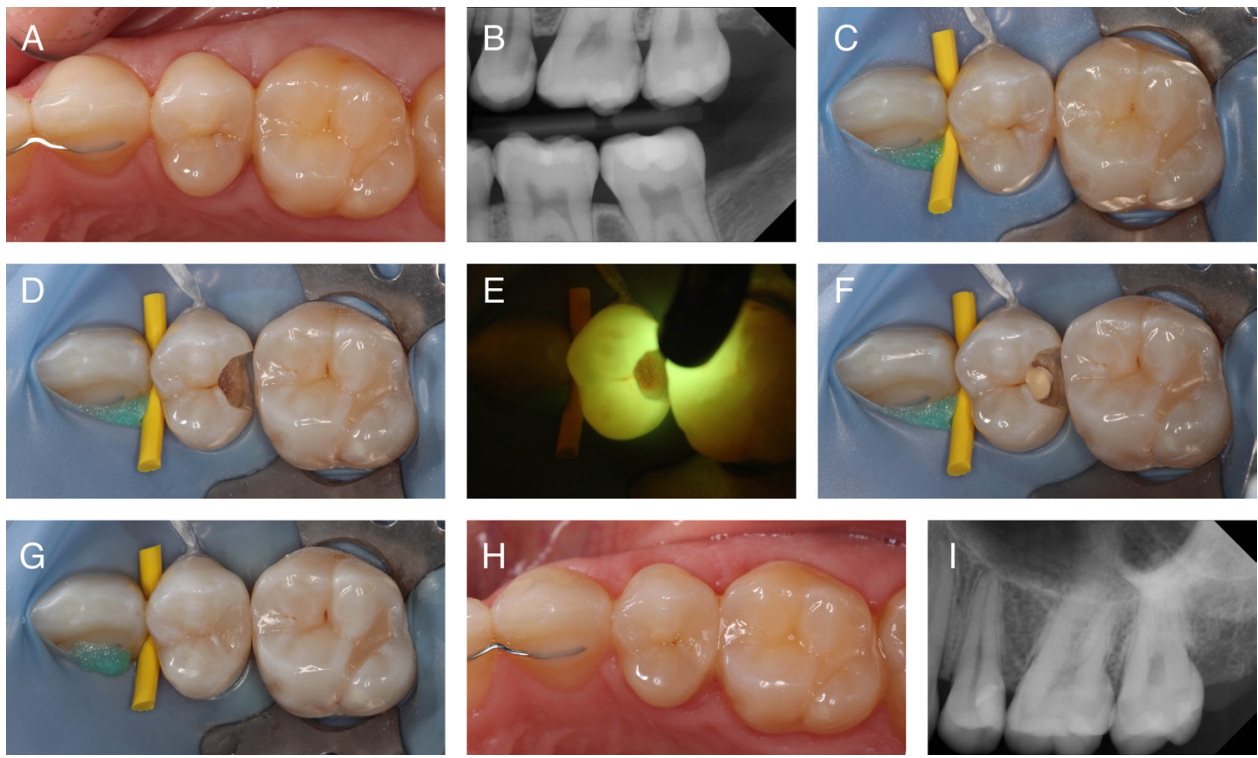

Figure 1 Exemplary caries treatment. (A) The distal ridge of tooth 25 revealed a grey discolouration, with no surface destruction visible. (B) For further diagnostics, a bitewing radiograph was taken, which showed carious decalcification on the distal tooth surface. (C) In the course of the therapy, the tooth was isolated with a rubber dam. (D) After preparation of an occlusal-distal cavity, the caries was removed carefully, and softened dentine was left near the pulp. (E) Complete removal of bacterially infected dentine at the cavity margins was verified by green fluorescence using violet excitation (fluorescence-aided caries excavation FACE, SIROInspekt, Sirona, Bensheim, Germany), red fluorescence was visible due to infected dentine at the dentine close to the pulp. (F) This area was covered by hydraulic calcium silicate cement (Biodentine, Septodont GmbH, Niederkassel, Germany) as a cavity liner. (G) Finally, the tooth was restored with a nanohybrid resin composite (Filtek Supreme, 3M Espe, Seefeld, Germany). (H) After 36 months, the filling appeared clinically intact and the tooth was sensitive to cold testing. (I) No pathological findings were visible radiologically.

aim at the remineralisation of defects comprising carious enamel and dentine with an intact surface, the need for excavation and restorative measures is claimed for cavitated lesions.

Various methods of caries removal have been described in the literature, which can be classified into three groups according to a consensus report published by Schwendicke et $a l^{5}$

- Non-selective caries removal (to hard dentine): All softened dentine is removed to dentine that is hard on probing in all parts of the cavity and the tooth is restored permanently.

- Selective caries removal (to firm or soft dentine): Caries is removed to dentine that is hard on probing in the periphery of the lesion, and to dentine which appears softened and still cuttable by excavators towards the pulp. After selective caries removal, a definitive restoration is placed immediately.

- Stepwise caries removal (in two visits): This treatment is performed in two sessions. In the first session, caries is removed in a selective approach and restored temporarily. After 6-12 months, the cavity is re-accessed, and residual caries is removed completely followed by definitive restoration.

Though still popular with many dentists, non-selective caries removal is no longer recommended in deep lesions and even considered as 'overtreatment' in the literature. ${ }^{7}$ Compared with selective or stepwise removal, it bears a higher risk of pulp exposure, a higher risk of passing toxic compounds, eg, monomers, through tubular dentine towards the pulp and constitutes an unnecessary weakening of the tooth. ${ }^{2}$ Stepwise removal is based on the idea of interrupting the progress of carious destruction, which facilitates a biological repair of the pulp-dentine complex by production of tertiary dentine in the interim period between temporary and definitive restoration. ${ }^{8}$ However, this procedure still comes with the risk of accidental pulp exposure during re-opening. Additionally, the seal of the temporary restoration can fail, and the overall treatment effort is higher due to multiple appointments. ${ }^{68}$ The approach of selective caries removal can be derived from observations made during the re-entry in cases of stepwise excavation, where former soft dentine became harder and less moist. It is seen as a cost-effective alternative in one visit with a low risk of accidental pulp exposure. Clinically, high chances of maintaining pulp vitality and improved long-term survival of teeth treated with selective caries removal have been described. ${ }^{69}$

\section{Rationale}

Overall, selective removal is regarded as a reasonable option for the treatment of deep carious lesions. Despite the advantages of selective caries removal, which have been described in numerous but heterogenous studies, ${ }^{10-14}$ it still remains unclear which biological processes take place within the pulpal tissue after this intervention and form the basis for success. A complex interplay between the residual microbes and the pulpal immune response 


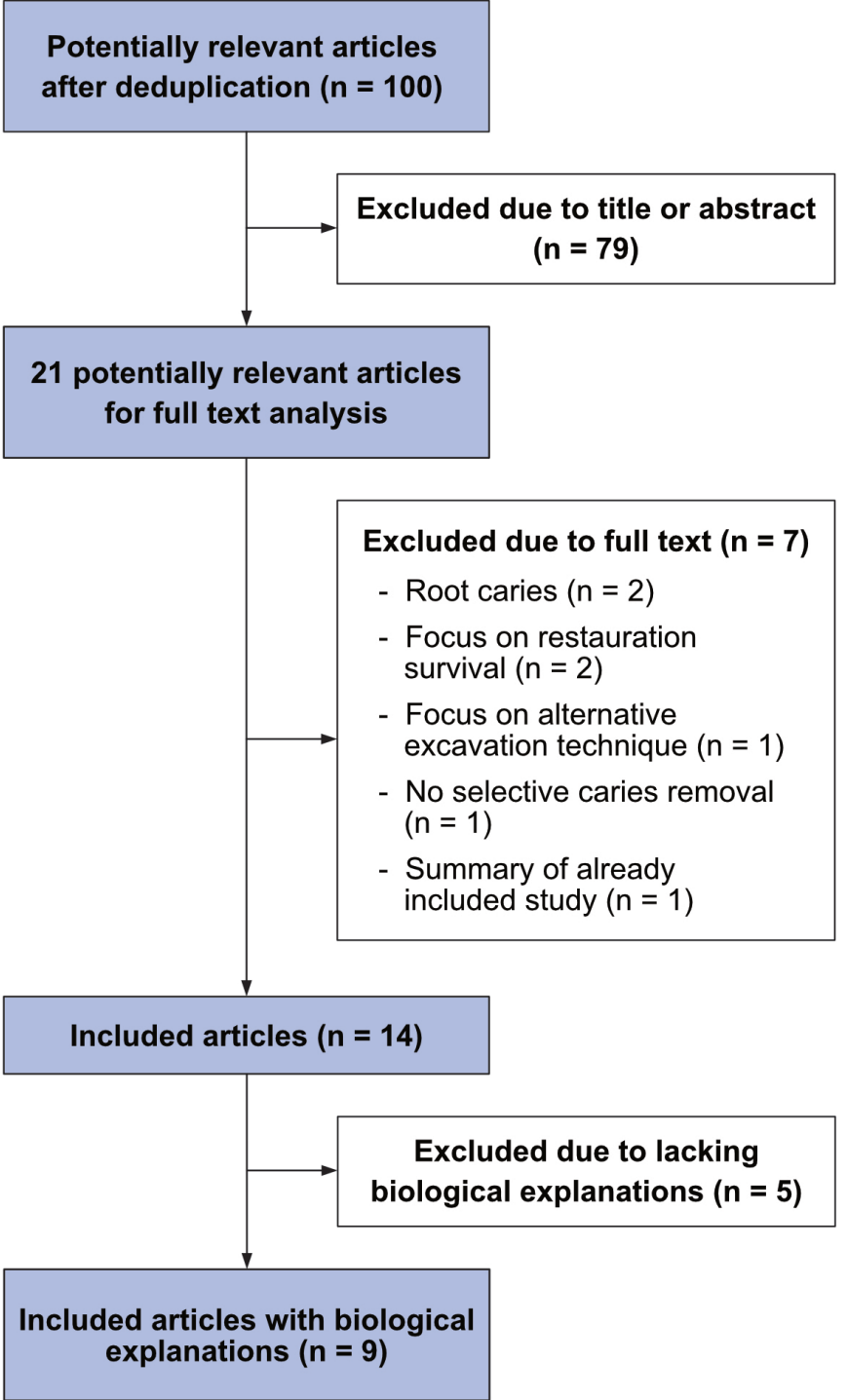

Figure 2 Flowchart of screening of all systematic reviews (phase I).

appears to induce formation of tertiary dentine and allows for the resolution of inflammation. However, no systematic and comprehensive review of literature is available on this matter. ${ }^{15}{ }^{16}$ A deeper understanding of the innovative approach of selective caries removal can contribute to a broader acceptance and implementation by dental professionals. ${ }^{6} 17$

\section{Scoping review objectives}

This scoping review aims to systematically assess the biological processes after selective caries removal in permanent teeth and to provide an overview of existing knowledge, outline the level of evidence for different aspects and thus identify gaps in knowledge that need to be addressed in the future.

In a first phase, important theories and key studies were identified by systematic searches, these were collected and summarised to define a scoping structure. Based on the findings, a systematic and structured scoping will be performed for all related aspects in a second phase.

\section{METHODS AND ANALYSIS}

Similar to systematic reviews, scoping reviews use a systematic approach to search, report and summarise existing evidence. Following the Preferred Reporting Items for Systematic reviews and Meta-Analyses extension for Scoping Reviews (PRISMA-ScR) guideline, this protocol details all methodological and analytical approaches study. ${ }^{18}$

\section{Phase I: definition of a scoping structure}

In order to identify key theories concerning the biological mechanisms behind selective caries removal, a comprehensive search of systematic reviews was carried out as they provide the highest level of evidence and cover the current state of knowledge comprehensively.

Therefore, the bibliographic database MEDLINE (Ovid) was searched where an initial, sensitive search strategy was developed that combined the concepts 'Population: Caries', 'Intervention: Selective removal' and 'Study type: Systematic Reviews' with the Boolean operator 'AND' (last search update: 16 June 2021). The phase I search strategy is provided in online supplemental file 1 . Only the most recent versions of updated studies were included.

Various clinical methods based on the concept of incomplete removal and subsequent sealing of infected dentine in permanent teeth were considered as they relate to similar biological mechanisms, for example, by including techniques that leave carious dentine behind, either permanently (eg, atraumatic restorative treatment (ART)) or temporarily (eg, stepwise removal). On the contrary, studies with a primary focus on deciduous teeth or studies on superficial enamel caries or exclusively with root caries were excluded. Furthermore, studies with a sole focus on alternative excavation or disinfection procedures (eg, laser-based or photodynamic techniques), on survival or mechanical characteristics of restorative materials or on other parameters not related to the specific research question (eg, treatment costs, patient satisfaction, teaching methodology) were not considered. Only publications in German or English were included.

Two reviewers (RW and KJS) screened the articles independently of one another in two stages ((1) abstracts and titles and (2) full texts) using the software Rayyan. ${ }^{19}$ Controversies were discussed and solved by vote of a third reviewer (MW). Initially, 21 of 100 potentially relevant articles were identified after screening abstracts and titles (figure 2). After a full-text analysis, 14 articles remained for an initial scoping of the topic. ${ }^{60-32}$ A data extraction form was used to compile the following information: authors, PubMed identifier (PMID), PubMed Central identifier (PMCID), digital object identifier (DOI), test and control groups, investigated outcomes and biological explanations.

The outcome measures of these 14 articles were fit to be assigned to four topical groups: clinical observations (sensitivity to cold, percussion test, etc), radiological outcomes, laboratory diagnostics (eg, histology, 
Table 1 Overview of 9 of 14 systematic reviews that explicitly comment on biological mechanisms and determinants

\begin{tabular}{|c|c|c|c|}
\hline Reference & Objective & Evaluated outcomes & Biological factors and explanations \\
\hline Mickenautsch et al $2010^{24}$ & $\begin{array}{l}\text { Pulp response in deep carious } \\
\text { lesions }\end{array}$ & $\begin{array}{l}\text { Histological, clinical and radiological pulp } \\
\text { reaction }\end{array}$ & $\begin{array}{l}\text { Thickness of remaining dentine } \\
\text { has an effect on pulp response } \\
\text { Cavity liner stimulates } \\
\text { odontoblasts to produce } \\
\text { reparative dentine and } \\
\text { remineralises existing dentine }\end{array}$ \\
\hline Hayashi et al $2011^{22}$ & $\begin{array}{l}\text { Stepwise removal at deep carious } \\
\text { lesions }\end{array}$ & $\begin{array}{l}\text { Pulp exposure or breakdown } \\
\text { Number of cariogenic bacteria in the } \\
\text { cavity } \\
\text { Colour and hardness of carious dentine } \\
\text { (production of tertiary dentin) } \\
\text { Retention of sealing material } \\
\text { Clinical success }\end{array}$ & $\begin{array}{l}\text { Cavity sealing limits nutrition of } \\
\text { residual bacteria to pulp serum } \\
\text { resulting in a shift in microbial diversity }\end{array}$ \\
\hline Ricketts et al $2013^{32}$ & $\begin{array}{l}\text { Stepwise removal, selective } \\
\text { removal and no dentinal caries } \\
\text { removal with cavity sealing }\end{array}$ & $\begin{array}{l}\text { Primary: dental pulp exposure during } \\
\text { removal, signs or symptoms of } \\
\text { pulpal disease, progression of caries, } \\
\text { restoration failure } \\
\text { Secondary: health economic measures, } \\
\text { oral health related to quality of life, } \\
\text { patients' and dentists' perceptions of } \\
\text { treatment, patients' discomfort during } \\
\text { treatment }\end{array}$ & $\begin{array}{l}\text { Arrest and reduction of bacteria } \\
\text { due to cavity sealing and loss of } \\
\text { substrates from oral cavity } \\
\text { Less complex microbial diversity } \\
\text { due to limitation on pulpal } \\
\text { substrates } \\
\text { Production of tertiary dentine } \\
\text { and tubular sclerosis reduce } \\
\text { permeability and limit pulpal } \\
\text { substrates for residual bacteria }\end{array}$ \\
\hline Schwendicke et al $2013^{27}$ & $\begin{array}{l}\text { Incomplete caries excavation (one- } \\
\text { step or two-step) }\end{array}$ & $\begin{array}{l}\text { Pulp exposure } \\
\text { Pulp symptoms } \\
\text { Failure of restoration } \\
\text { Caries progression }\end{array}$ & Arrest of caries by seal of the lesion \\
\hline Schwendicke et al $2013^{28}$ & $\begin{array}{l}\text { Incomplete caries excavation (one- } \\
\text { step or two-step) }\end{array}$ & Clinical or radiological failure & $\begin{array}{l}\text { Dentine remineralisation } \\
\text { Caries arrest by sufficient cavity } \\
\text { seal limits the supply of nutrients }\end{array}$ \\
\hline Schwendicke et al $2015^{29}$ & $\begin{array}{l}\text { Carious lesion with any excavation } \\
\text { technique and the use of cavity } \\
\text { liner }\end{array}$ & $\begin{array}{l}\text { Primary: number of positive bacterial } \\
\text { dentine samples remaining in a cavity } \\
\text { Secondary: reduction in the numbers of } \\
\text { bacteria remaining in the cavity }\end{array}$ & $\begin{array}{l}\text { Cavity liners induce reactionary } \\
\text { dentine, reduce postoperative pulpal } \\
\text { inflammation, protect the pulp and } \\
\text { have antibacterial effects }\end{array}$ \\
\hline $\begin{array}{l}\text { Schenkel and Veitz-Keenan } \\
2019^{26}\end{array}$ & $\begin{array}{l}\text { Permanent posterior teeth of } \\
\text { different caries depth restored with } \\
\text { composite and the use of cavity } \\
\text { liners }\end{array}$ & $\begin{array}{l}\text { Primary: postoperative hypersensitivity, } \\
\text { restoration failure } \\
\text { Secondary: material costs, adverse } \\
\text { events (eg, pulpal involvement, tooth } \\
\text { fracture or hypersensitivity to materials) }\end{array}$ & $\begin{array}{l}\text { Pulpal reaction most likely from } \\
\text { bacteria and their products, rather } \\
\text { than from composite restorative } \\
\text { materials } \\
\text { Seal of dentinal tubules by cavity } \\
\text { liners } \\
\text { Stimulation of favourable pulp } \\
\text { reactions } \\
\text { Medication and sedation of pulp } \\
\text { (especially zinc oxide eugenol) } \\
\text { Stimulation of reparative dentine } \\
\text { formation (especially calcium } \\
\text { hydroxide) }\end{array}$ \\
\hline
\end{tabular}

microbiology) and other outcomes (treatment costs, patient satisfaction, etc). However, both clinical and radiological outcomes are not suitable to assess biological mechanisms in the pulp-dentine complex after selective caries removal. A detailed evaluation of the biological processes after selective caries excavation was not the primary goal of most investigations, but some conducted microbiological analyses and histological examination 
Table 2 Categories for biological processes and influencing factors at selective caries removal

\begin{tabular}{ll}
\hline Subgroup & Relevant parameters \\
\hline Remaining bacteria & $\begin{array}{l}\text { Reduced activity or arrest } \\
\text { Reduction of bacterial counts } \\
\text { Reduction of diversity } \\
\text { Change of metabolism }\end{array}$ \\
\hline Pulp response & Dentine thickness and \\
& permeability \\
& Patient age \\
& Dentinogenesis (tertiary, \\
& peritubular, sclerosis) \\
& Infected dentine \\
& Blockade or change of \\
Cavity seal & substrates (eg, pulp serum) \\
& Remineralisation by pulpal fluid \\
& Inhibition of demineralisation \\
Cavity liner & Antibacterial effects \\
& Remineralisation \\
& Pulp stimulation or sedation \\
& Pulp protection \\
& Occlusion of tubules \\
\hline
\end{tabular}

of extracted teeth. ${ }^{6222429}$ Furthermore, only 9 of the included 14 systematic reviews (64\%) offered biological explanations at all, which were summarised in table 1 .

Based on this information, all biological theories or influencing factors were summarised and categorised into four thematical groups (table 2) that will serve as the lead structure for phase II of this scoping review.

\section{Phase II: scoping of the literature and mapping of evidence} Search strategy and terms

Theories and single aspects as identified during phase I will be systematically investigated in an iterative, explorative process using established search techniques. ${ }^{33} 34$ Each category will be searched individually to gain more insights in regard to the respective topics:

For a few key articles identified during phase I, similar articles linked in PubMed will be accessed for further screening. In a divide-and-conquer approach, facetspecific search strategies will be built and added with an AND operator to the subject-specific search strategy from phase I (see online supplemental file 1) in the MEDLINE database. ${ }^{34}$ An exemplary search strategy for the category 'Remaining bacteria' is shown in online supplemental file 2. This will be amended by 'exploratory pearl growing' - and 'berry picking' - approaches as deemed appropriate. $^{33}{ }^{34}$ Further databases such as Science Citation Index Expanded (Web of Science) and Google Scholar will be employed at this rather informal stage of the search process. Reference lists of relevant articles will be screened in addition.

Records from the database and manual searches will be collected and deduplicated by use of Citavi software (V.6; Swiss Academic Software GmbH, Wädenswil, Switzerland). The search process will be documented in a PRISMA-ScR
Table 3 Types of primary research (modified according to 35). The study types serve as the organisational basis for the narrative summary of all scoping results

\begin{tabular}{|c|c|c|}
\hline \multicolumn{2}{|l|}{ Class } & Study type \\
\hline \multicolumn{2}{|l|}{$\begin{array}{l}\text { Applied basic } \\
\text { research }\end{array}$} & $\begin{array}{l}\text { Animal study } \\
\text { Cell study } \\
\text { Genetic } \\
\text { engineering/gene } \\
\text { sequencing } \\
\text { Biochemistry } \\
\text { Material } \\
\text { development } \\
\text { Genetic studies }\end{array}$ \\
\hline \multirow[t]{2}{*}{ Clinical research } & Experimental & $\begin{array}{l}\text { Clinical study } \\
\text { (Phase I-IV) }\end{array}$ \\
\hline & Observational & $\begin{array}{l}\text { Therapy } \\
\text { study (without } \\
\text { intervention) } \\
\text { Prognostic study } \\
\text { Diagnostic study } \\
\text { Observational study } \\
\text { with drugs } \\
\text { Secondary data } \\
\text { analysis } \\
\text { Case series } \\
\text { Sigle case report }\end{array}$ \\
\hline \multirow[t]{2}{*}{$\begin{array}{l}\text { Epidemiological } \\
\text { research }\end{array}$} & Experimental & $\begin{array}{l}\text { Field study } \\
\text { Group study }\end{array}$ \\
\hline & Observational & $\begin{array}{l}\text { Cohort study } \\
\text { (prospective, } \\
\text { historical) } \\
\text { Case control study } \\
\text { Cross-sectional } \\
\text { study } \\
\text { Ecological study } \\
\text { Monitoring, } \\
\text { surveillance } \\
\text { Description with } \\
\text { registry data }\end{array}$ \\
\hline
\end{tabular}

flowchart. By organising the screening process according to topic (table 2), more targeted searches will be enabled and with lower chances to miss out on relevant study.

\section{Study selection}

In order to achieve broad scoping of the topic, both preclinical as well as clinical research will be considered relevant if information regarding the categories as defined in phase I was provided. Of special interest are articles that specifically aim at the description of biological mechanisms after selective caries removal. Clinical studies will be considered if they include specific information on microbiological or histological findings or alternative diagnostic methods that provide insights into related processes at a cellular level. Further terms can be added throughout the iterative search process (no clinical or radiological observations). Items must be published in English or German. Narrative reviews, books, book chapters, editorials or commentaries will be 
excluded. By limiting relevant items to original articles that have been subjected to peer review, the focus of this scoping review will be directed towards available scientific evidence. Subjective theories or opinions of individuals or groups within the research field will be avoided in order to achieve the highest level of objectivity.

\section{Screening process}

In accordance with the standards for scoping reviews, searches as well as inclusion or exclusion of articles will be performed according to the PRISMA-ScR guidelines. ${ }^{18}$ The items will not be assessed in regard to their quality, as the synthesis and description of evidence are the goals of a scoping review. However, classification of the included items according to their study type (table 3) will be performed to identify potential structural scientific gaps. $^{35}$

The screening process will be blinded with help of the software Rayyan. ${ }^{19}$ In accordance to the first phase of the search, articles will be screened for inclusion first based on title and abstract, and by subsequently full-text review. The decision process will be conducted by two independent reviewers, where controversies were discussed and resolved by vote of a third reviewer.

\section{Data charting process}

Two reviewers will simultaneously chart data and findings from included studies by use of a data charting form. This form will include following categories:

- Background information (eg, author, date, setting, study objective).

- Population.

- Details on relevant outcomes (both quantitative and qualitative) with respect to the particular thematic search.

- Study type (table 3).

Because this scoping review intends to synthesise and describe the scope of evidence, the risk of bias will not be assessed for individual studies. A detailed, tentative data extraction template is available as online supplemental file 3 . The charting will be updated in an iterative process and a rationale for major revisions will be given for the respective items.

\section{Data synthesis}

Relevant data will be charted in a tabular form according to the structure as defined during the phase I search and grouped according to the initially defined categories. Additionally, all studies will be sorted according to the types specified in table 3 . All information compiled during this scoping process will be summarised in a narrative way to create a map of evidence in regard to the biological basis of selective caries removal. Tables and charts will be used in addition for the presentation of relevant results.

\section{Patient and public involvement}

No patient was involved in the conduct of the study. The required informed consent of the patient used as an example case in the introduction was obtained according to the guidelines of the General Medical Council and the Committee on Publication Ethics.

\section{Ethics and dissemination}

Since no primary data are collected in this study, formal approval by an ethics committee is not required.

The results of this review are used to map the scientific evidence related to the biology behind selective excavation of caries. This structured summary of existing knowledge provides scientific and dental practitioners with an organised and substantiated insight into the topic. Furthermore, the systematic synopsis may also serve as a basis for future research efforts to address current gaps of knowledge in this field. Results of this scoping review will be structured according to the PRISMA-ScR checklist, published in a peer-reviewed journal and disseminated further to stakeholders through presentations at conferences or short summaries. ${ }^{18}$ If changes to the protocol are necessary after publication, these will be described in detail, documented with the appropriate date, and a rationale will be provided.

Contributors All authors participated in the development and design of the study protocol. MW, KJS, KMG, WB and RW drafted the manuscript. HK and RW performed the preliminary search of the literature. RW, KJS and MW screened the abstracts, titles and full texts of these articles. All authors read and approved the final study protocol. MW acted as the guarantor of this work.

Funding The authors have not declared a specific grant for this research from any funding agency in the public, commercial or not-for-profit sectors.

Competing interests None declared.

Patient and public involvement Patients and/or the public were not involved in the design, or conduct, or reporting, or dissemination plans of this research.

Patient consent for publication Not applicable.

Provenance and peer review Not commissioned; externally peer reviewed.

Supplemental material This content has been supplied by the author(s). It has not been vetted by BMJ Publishing Group Limited (BMJ) and may not have been peer-reviewed. Any opinions or recommendations discussed are solely those of the author(s) and are not endorsed by BMJ. BMJ disclaims all liability and responsibility arising from any reliance placed on the content. Where the content includes any translated material, BMJ does not warrant the accuracy and reliability of the translations (including but not limited to local regulations, clinical guidelines, terminology, drug names and drug dosages), and is not responsible for any error and/or omissions arising from translation and adaptation or otherwise.

Open access This is an open access article distributed in accordance with the Creative Commons Attribution Non Commercial (CC BY-NC 4.0) license, which permits others to distribute, remix, adapt, build upon this work non-commercially, and license their derivative works on different terms, provided the original work is properly cited, appropriate credit is given, any changes made indicated, and the use is non-commercial. See: http://creativecommons.org/licenses/by-nc/4.0/.

\section{ORCID iDs}

Matthias Widbiller http://orcid.org/0000-0002-7917-9466

Konstantin J Scholz http://orcid.org/0000-0003-4450-4238

\section{REFERENCES}

1 Vos T, Barber RM, Bell B, et al. Global, regional, and national incidence, prevalence, and years lived with disability for 301 acute and chronic diseases and injuries in 188 countries, 1990-2013: a systematic analysis for the global burden of disease study 2013 . The Lancet 2015;386:743-800.

2 Innes NPT, Frencken JE, Bjørndal L, et al. Managing carious lesions: consensus recommendations on terminology. Adv Dent Res 2016;28:49-57. 
3 Takahashi N, Nyvad B. Ecological hypothesis of dentin and root caries. Caries Res 2016;50:422-31.

4 Byers MR, Närhi MVO, Mecifi KB. Acute and chronic reactions of dental sensory nerve fibers to cavities and desiccation in rat molars. Anat Rec 1988;221:872-83.

5 Schwendicke F, Frencken JE, Bjørndal L, et al. Managing carious lesions. Adv Dent Res 2016;28:58-67.

6 MMAF B, De Queiroz Rodrigues MI, FWMG M. Selective, stepwise, or nonselective removal of carious tissue: which technique offers lower risk for the treatment of dental caries in permanent teeth? A systematic review and meta-analysis. Clin Oral Invest 2020;24:521-32.

7 European Society of Endodontology (ESE) developed by:, Duncan HF, Galler KM, et al. European Society of Endodontology position statement: management of deep caries and the exposed pulp. Int Endod J 2019;52:923-34.

8 Maltz M, Henz SL, de Oliveira EF, et al. Conventional caries removal and sealed caries in permanent teeth: a microbiological evaluation. $J$ Dent 2012;40:776-82.

9 Maltz M, Koppe B, Jardim JJ, et al. Partial caries removal in deep caries lesions: a 5-year multicenter randomized controlled trial. Clin Oral Investig 2018;22:1337-43.

10 Jardim JJ, Mestrinho HD, Koppe B, et al. Restorations after selective caries removal: 5-year randomized trial. J Dent 2020;99:103416.

11 Bjørndal L, Simon S, Tomson PL, et al. Management of deep caries and the exposed pulp. Int Endod $J$ 2019;52:949-73.

12 Elhennawy K, Finke C, Paris S, et al. Selective vs stepwise removal of deep carious lesions in primary molars: 24 months follow-up from a randomized controlled trial. Clin Oral Investig 2021;25:645-52.

13 Ricucci D, Siqueira JF, Rôças IN, et al. Pulp and dentine responses to selective caries excavation: a histological and histobacteriological human study. J Dent 2020;100:103430.

14 Scholz KJ, Hinderberger M, Widbiller M, et al. Influence of selective caries excavation on marginal penetration of class II composite restorations in vitro. Eur J Oral Sci 2020;128:405-14.

15 Larmas M, Sándor GKB. Enzymes, dentinogenesis and dental caries: a literature review. JOMR 2014;5:e3.

16 Farges J-C, Alliot-Licht B, Renard E, et al. Dental pulp defence and repair mechanisms in dental caries. Mediators Inflamm 2015;2015:1-16.

17 Schwendicke F, Göstemeyer G. Understanding dentists' management of deep carious lesions in permanent teeth: a systematic review and meta-analysis. Implementation Sci 2016;11:142.

18 Tricco AC, Lillie E, Zarin W, et al. PRISMA extension for scoping reviews (PRISMA-ScR): checklist and explanation. Ann Intern Med 2018;169:467-73.

19 Ouzzani M, Hammady H, Fedorowicz Z, et al. Rayyan-a web and mobile APP for systematic reviews. Syst Rev 2016;5:1-10.
20 Bergenholtz G, Axelsson S, Davidson T, et al. Treatment of pulps in teeth affected by deep caries - a systematic review of the literature. Singapore Dent J 2013;34:1-12.

21 Rosa WLO, Lima VP, Moraes RR, et al. Is a calcium hydroxide liner necessary in the treatment of deep caries lesions? A systematic review and meta-analysis. Int Endod J 2019;52:588-603.

22 Hayashi M, Fujitani M, Yamaki C, et al. Ways of enhancing pulp preservation by stepwise excavation-A systematic review. J Dent 2011;39:95-107.

23 Hoefler V, Nagaoka H, Miller CS. Long-Term survival and vitality outcomes of permanent teeth following deep caries treatment with step-wise and partial-caries-removal: a systematic review. J Dent 2016;54:25-32.

24 Mickenautsch S, Yengopal V, Banerjee A. Pulp response to resin-modified glass ionomer and calcium hydroxide cements in deep cavities: a quantitative systematic review. Dental Materials 2010;26:761-70.

25 Miyashita H, Worthington HV, Qualtrough A, et al. Withdrawn: pulp management for caries in adults: maintaining pulp vitality. Cochrane Database Syst Rev 2016;11:CD004484.

26 Schenkel AB, Veitz-Keenan A. Dental cavity liners for class I and class II resin-based composite restorations. Cochrane Database Syst Rev 2019;3:CD010526.

27 Schwendicke F, Dörfer CE, Paris S. Incomplete caries removal: a systematic review and meta-analysis. J Dent Res 2013;92:306-14.

28 Schwendicke F, Meyer-Lueckel H, Dörfer C, et al. Failure of incompletely excavated teeth-A systematic review. J Dent 2013;41:569-80.

29 Schwendicke F, Tu Y-K, Hsu L-Y, et al. Antibacterial effects of cavity lining: a systematic review and network meta-analysis. J Dent 2015;43:1298-307.

30 Dorri M, Martinez-Zapata MJ, Walsh T, et al. Atraumatic restorative treatment versus conventional restorative treatment for managing dental caries. Cochrane Database Syst Rev 2017;12:CD008072.

$31 \mathrm{Li} \mathrm{T}$, Zhai X, Song F, et al. Selective versus non-selective removal for dental caries: a systematic review and meta-analysis. Acta Odontol Scand 2018;76:135-40.

32 Ricketts D, Lamont T, Innes NPT, et al. Operative caries management in adults and children. Cochrane Database Syst Rev 2013;28:CD003808

33 Gusenbauer M, Haddaway NR. Which academic search systems are suitable for systematic reviews or meta-analyses? evaluating retrieval qualities of Google Scholar, PubMed, and 26 other resources. Res Syn Meth 2020;11:181-217.

34 Booth A. Unpacking your literature search toolbox: on search styles and tactics. Health Info Libr J 2008;25:313-7.

35 Röhrig B, du Prel J-B, Wachtlin D, et al. Types of study in medical research: Part 3 of a series on evaluation of scientific publications. Dtsch Arztebl Int 2009;106:262-8. 